\title{
DEBATES
}

\section{What is left of the protests? Social movements and youth empowerment in Brazil}

\author{
O que resta dos protestos? Movimentos sociais e empoderamento da \\ juventude no Brasil
}

\section{Magda Pischetola}

\begin{abstract}
Over the past few years, new forms of socialization of politics through social media have found expression in collective mobilizations. The paper examines the case of the recent uprisings in Brazil. It presents the results of a qualitative research carried out between June 2013 and June 2015, with focus on the actors involved, their reasons to participate, as well as the continuity of their action. Three research tools were used in the study: social media mapping, an online survey and interviews with activists. The findings give credit to the existence of a connective logic on the social networks, as they illustrate that what attracted the masses in June 2013 was mainly the 'event of a protest'. Nevertheless, political engagement was found to increase in smaller circles, among groups of youth who got involved during the uprisings, and are motivated by the idea of a political resistance up to present days.
\end{abstract}

\section{Keywords}

Social Movements; Youth Participation; Communication Networks; Social Media.

\section{Resumo}

Nos últimos anos, novas formas de socialização da atividade política através das mídias sociais têm encontrado expressão em mobilizaçóes coletivas. O artigo examina as recentes manifestaçóes no Brasil, apresentando os resultados de uma pesquisa qualitativa realizada entre Junho de 2013 e Junho de 2015, com foco nos atores envolvidos, suas razóes para participarem e a continuidade de sua ação. Três instrumentos de pesquisa foram utilizados no estudo: um mapeamento inicial das mídias sociais, um breve questionário on-line e algumas entrevistas com ativistas. Os resultados mostram a existência de uma "lógica conectiva" nas redes sociais e ilustram que o que atraiu as massas em junho de 2013 foi principalmente o "evento" de um protesto. No entanto, verifica-se que o engajamento político dos jovens está aumentando aos poucos, entre grupos que se envolveram durante os protestos e continuam motivados pela ideia da resistência política até os dias de hoje.

\section{Palavras-chave}

Movimentos Sociais; Participação dos Jovens; Redes de Comunicação; Mídias Sociais. 


\section{Introduction}

Over the last decade, it has been pointed out that forms of social interaction and reproduction, which characterise social networks, such as Facebook and Twitter, offer numerous opportunities for pluralism in public debates and enhance so-called participatory democracy (REEDY \& WELLS, 2009; DIJK, 2012). This view emphasises the socialization of politics and encouragement of active citizenship through digital media, which have found expression through mass protests in different countries in the last few years.

In a review of the literature, we find considerable evidence that civil society has increased its opportunities of resistance with the emergence of digital networks. As scholars have paid more attention to the issue, the complexity of the phenomenon has become more visible, and has raised further questions: what are the factors of success in the communication for social change? And how does communication on social media work, giving the non-linear, plural, and transversal nature of youth participation to the protests?

Castells (2012) has theorised the existence of a "mass self-communication", which describes the autonomous and very personal way of processing messages allowed by digital platforms. It is "self-communication" because the production of the message is self-generated, self-directed and self-selected:

By engaging in the production of mass media messages, and by developing autonomous networks of horizontal communication, citizens of the Information Age become able to invent new programs for their lives with the materials of their suffering, fears, dreams and hopes. They build their projects by sharing their experience. They subvert the practice of communication as usual by occupying the medium and creating the message (CASTELLS 2012, p. 9).

At the same time, this is "mass communication" because it can potentially reach a global audience through the Internet. Thus, in this model, the different forms of communication (interpersonal, mass and mass self-communication) coexist and complement each other.

Following the analysis of Castells, Gutierrez (2013) suggests that, rather than ideological components or concrete reason, what made the recent protests so massive is a "new architecture of calling", built around causes that are easy to agree with and, therefore, are able to bring together even antagonist ideologies. Along the same line of thought, Bennett and Segerberg (2013) examine the organisational dynamics that 
emerge when communication becomes a prominent part of social movements. And to do so, they distinguish between two macro categories of patterns that characterise the digitally enabled networks of action: one that follows the familiar logic of collective action, based on organisational resources and the configuration of collective identities. And a second, less familiar, logic of connective action, made possible by personalised content sharing on social media. The first pattern of action gets a benefit from the digital media, but it is not drastically changed by it. Established organisations such as NGOs, political parties, press and unions keep their active role behind collective actions, even though they step back from assuming the leadership publicly and, in doing so, give space to new and non conventional actions. They achieve broad public engagement by spreading easy-to-personalise issues through social media. On the other hand, the pattern of connective action is absolutely dependent on media networks and the possibilities ICT offers to the users. In this network mode, according to the authors, technology itself takes the role of established political organisations, with broader results:

\footnotetext{
compared to many conventional social movement protests with identifiable membership organisations leading the way under common banners and collective identity frames, these more personalised, digitally mediated collective action formations have frequently been larger; have scaled up more quickly; and have been flexible in tracking moving political targets and bridging different issues (BENNETT \& SEGERBERG, 2013, p. 6).
}

In Bennett and Segerberg's considerations, connective action might weaken collective action and not enhance deeper forms of engagement. Or they may be even more effective than traditional ones, as far as they give visibility to a cause, and catch the attention of the media.

According to Gerbaudo (2012, p. 4), social media is not to be seen as "automatically suitable or unsuitable as means of mobilisation". The crucial question to be asked, the author says, is how do thousands of participants interact and mediate with the new forms of public gatherings, and how do they act as a "one", despite their differences. Which means that we should also try to understand what is the imbrication between media and local contexts of political action. With this purpose, we should consider that the digital tools are changing the nature of groups, norms, social formations, and power, determining new communication practices. In a 


\section{4 | Magda Pischetola}

number of "micro-operations", analysed by Bennett, Segerberg and Walker (2014), the multiple crowd's contributions like tweeting, retweeting, posting and sharing seem to belong to one common voice, an agent that summarises peoples' different causes and ideas. According to the authors, that happens, precisely, because of the observed processes of crowd-enabled connective action such as was found in the Arab Spring, the $15-\mathrm{M}$ in Spain, and Occupy Wall Street. In massive social protests, crowds are found to elaborate peer-communication practices which allow them to organise, gather and act in a new connective frame based on networking. As Chadwick (2013, p. 22) explains:

Political narratives must be woven across a number of media to be effective. This change has meant that politics is increasingly defined by the organisations, groups, and individuals who best blend the technologies, genres, norms, behaviours, and organisational forms associated with older and newer media. Power is now wielded by those who create, tap, and steer information flows in ways that modify, enable, and disable the power of others, across and between a range of media environments (CHADWICK, 2013, p. 22).

The crucial step, adds Van Dijk (2012), seems to be transforming information into political action. Which is not only a matter of personal motivation, but also of social relationships of power in the political system and in the media.

These insights pose more questions than they answer. How do the leadership and the online organisation of protests work? What is the social, economical and political profile of the leaders? Do the political parties have a role in the mobilisation? What is the relationship between online visibility/popularity and political engagement? Starting from these inquiries, this paper analyzes the changing face of massive popular protests from a critical perspective, exploring what the role of social media is in the organisational dynamics of the mass uprisings. It will present the results of a qualitative study on the most active pages of social media in the popular movements of Brazil in 2013, as well as the continuity of their political influence up to present days. 


\section{A case study of the protests in Brazil}

This study investigates the recent social movements in Brazil, which has appeared to be a phenomenon that fell outside the left-right dual division of society, and was largely leaderless.

Sparked by a 20 -cent increase in the ticket price of public transport in June 2013, uprisings in Brazil have grown into mobilizations against corruption in the government, the high costs of hosting the World Cup in 2014, the lack of investments in public services, as well as specific demands from professional groups and minorities. The first "call to action" (CASTELLS, 2012) was spread through social media and gathered over one million people on the streets of São Paulo on the $16^{\text {th }}$ and $17^{\text {th }}$ of June, with similar results in Rio de Janeiro on the $20^{\text {th }}$ of June. In spite of the massive participation online and offline, as well as the presence of different causes and ideologies, no official leaders appeared and no public speeches were given. Information would circulate on Facebook pages and through Twitter accounts, displaying sometimes a very high number of followers and comments, as well as shared images and videos about the ongoing events.

In order to get a picture of the actors involved, the reasons of their participation in the uprisings of June 2013, as well as the continuity of their action, a qualitative research study was carried out between June 2013 and June 2015, with the use of three different research tools: (1) Social media mapping and longitudinal discourse analysis; (2) Online survey published on the most active Facebook pages; (3) In-depth interviews with four activists.

During the protests, digital tweets and posts of the "authorities" (KLEINBERG, 1999) were followed by users who apparently considered the source trustable or recognizable, before the message could become "viral" and attract the mass. In other words, the individual's participation was guaranteed when a large number of people in their network were also participating in the event. The first objective of the research was analyzing if there were any leaders or organisers of the protests "events". Social media functioned a call for action, but who was responsible for the first initiative? Was there a political agenda? And was it declared or hidden?

By using software capable of mapping the spread of messages on social networks, the responsibility of some specific groups in mass mobilization became evident, specifically: a) Profiles of the press; b) Opponents to the government; c) Groups representing minorities; and d) Supporters of the government (INTERAGENTES, 2013). Considering this, the "authorities" were filtered, by 
excluding those pages that were created by political parties or by the press. This way, it was possible to compare the activity of the 25 most recognised pages/accounts in June 2013 with their activity one and two years later. An additional follow-up study took place to gain a broader picture of this phenomenon, in the form of a survey on the 25 Facebook and Twitter accounts that were most active during the protests under analysis. Given the relatively small sample, we managed to access $(\mathrm{N}=52)$, we have to be cautious about building generalizations. Nonetheless, the results show some interesting findings. Finally, some of the respondents were contacted for an indepth interview, and more interesting and unexpected findings emerged in the research. They will be presented in the subsequent sections.

\section{Analysis and results}

The design of the research proposal was correlational and descriptive, with information collected over two years. In this section, we explore the results obtained transversally in all the phases of the research, following the description of the main objective under scrutiny.

- Who were the leaders of the protests?

The results showed that, after one year, $48 \%$ of the 25 most active pages/accounts did not have a meaningful participation anymore, but 13 of the initial 25 authorities continued to exhibit a high level of activity, which we have measured by the "People talking about this" function of the social network (number of users that interacted with the page in a seven-day period). At the top of the list are the most general and broad causes for indignation, like corruption and the lack of representativeness of political parties. In 2015 only five out of these 13 are still considerably active: three pages with $50-80 \%$ of previous activity and two with higher activity. It can be seen from the data in Table 1 that the "Mobilização Patriota" (Patriot Mobilization) and "Revoltados Online" (Angry Online) pages reported significantly more "People talking about it" than all the other pages. Interestingly enough, the contents of these pages are extremely right-sided, nationalist and very critical to the government and the party represented by president Dilma, who has largely lost her popularity in spite of being re-elected in 2014. 
Table 1 - Authoritative pages still active on Facebook one year after the first protests

\begin{tabular}{c|c|c|c}
\hline \multirow{2}{*}{ Facebook Page } & \multirow{2}{*}{ Category } & \multicolumn{2}{c}{ People talking about this } \\
\cline { 3 - 4 } & & $\begin{array}{c}\text { June 2014 } \\
\text { one year later }\end{array}$ & $\begin{array}{c}\text { June 2015 } \\
\text { two years later }\end{array}$ \\
\hline Movimento Contra Corrupção & Cause & 451.000 & 235.000 \\
\hline FORA PT & Political organisation & 241.200 & 69.000 \\
\hline AnonymousBrasil & Cause & 104.300 & 15.400 \\
\hline Dilma Rousseff NÃO & Community & 79.200 & 63.000 \\
\hline Movimento Contra Corrupção-SP & Cause & 69.300 & 45.100 \\
\hline Organização de Combate à Corrupção & Community & 63.400 & 33.500 \\
\hline Povo Brasileiro & Political organisation & 59.600 & 5.200 \\
\hline Mobilização Patriota & Political organisation & 32.000 & 85.700 \\
\hline Revoltados ON LINE & Community & 27.800 & 369.000 \\
\hline Diário de Hospital & Community & 27.100 & Page removed \\
\hline PT da Depressão & Politician / public figure & 22.400 & 898 \\
\hline Impeachment do Renan Calheiros & Politician / public figure & 16.200 & 3.300 \\
\hline Eu não voto em Dilma & Community & 14.400 & Page removed \\
\hline
\end{tabular}

Active pages 2013-2015 $\square$ More active pages in 2015 than in 2013

Source: Author's data, social media mapping on-line.

One of the interviewed activists confirmed and explained this political phenomenon, defining the differences between protests occurred in 2013 and the more recent protests against the government:

In the protests of 2013, there were all kind of people: left-sided, right-sided, people who were there just for curiosity or for fun, there was all this. Nowadays, in this new phenomenon, you see a group of people that don't know exactly what they want, but they're against corruption, and right-sided people and of the extreme right too... People who are calling for dictatorship, or who want that Aecio (right-wing candidate to presidency at the last elections, editor's note) wins, calling for Dilma's impeachment. I mean, the agenda is very different than in 2013, and I do not recognise myself in it anymore. These guys, to me, come from a different world, especially when they say that, during dictatorship, it was all better than it is now. They don't have any historical awareness and they don't mind about it, they don't even look for it. They take as a reference something they 
don't know [...] and they use it to protest against a bunch of things that they connect with the government, which is mainly the social agenda of the government. In reality, it's a social movement that's anti-social!

When asked about their perception of some kind of leadership present during the manifestations in 2013, the activists rejected strongly the idea of the mass being maneuvered by political leaders. It appears clear that new forms of political dialogue were discussed within the uprisings: a dialogue that excludes the figure of the leader as "someone that represents me" and, eventually, accepts the presence of leaders for logistic, organisational reasons. For example, one interviewee said:

It is complicated to talk about a leadership... There was no leadership there. I'd say there were some protagonists, who emerged among the people. Now, when the police repression started, they were looking for leaders, and they just chose some people to become the scapegoat, and they managed to scare people this way, especially the poorest ones, who are always the weakest in terms of rights and possibility to defend themselves [...]. I am not against leaders, but I think that the protagonists who were acting during protests, even myself, had the role of going against leadership. I mean, the anarchist ideals support the existence of horizontal relationship. I identify with this much more. Leadership gives me the idea of verticality of processes. It doesn't interest me. [...] A leader comes here and says: you do this, you do that. A protagonist says: look, I am doing this, if you want to join, it's fine, if not, I'll do it anyway. It's selfmanagement, you know? You take the responsibility for your action. Leadership is different... Leadership is when you take the responsibility of everybody's action. [...] The other one might even mirror himself in you, identify with you, and appreciate your initiative... Even your courage, let's say. But, if they want you as a leader, you might not want it... You don't want to represent another one. Because these movements started with this idea: they do not represent me! In other words, if someone said that I represent them, well, this sentence does not represent me!

Another interviewee alluded to the notion of leadership as logistics and organisation: 
I think that it was a horizontal movement, but there were leaderships, organised group who would plan the actions on the streets. It's a leadership that does not depend on a formal title, but depends on personalities. Some groups had more hegemony than others, and would decide the priorities in the agenda... But these leaderships were not crystallised. They didn't control the movements, they organised them.

In conclusion, the image that Gerbaudo (2012) creates the one of choreographers - rather than leaders - sounds perfectly appropriate to the model here exposed. In the words of the author:

The introduction of social media in social movements does not simply result in a situation of absolute spontaneity and unrestrained participation. On the contrary, influential Facebook admins and activist tweets become 'soft leaders' or choreographers, involved in setting the scene, and constructing an emotional space within which collective action can unfold (GERBAUDO, 2012).

- What were the reasons to protest?

Respondents to the online survey $(\mathrm{N}=52)$ were asked to indicate the most important causes that in their opinion mobilised people to protest in 2013 and which of those causes would be still important for them at the time of the survey (one year later). From the chart, it can be seen that by far the greatest demand is for public Education and Health services and against political corruption. 
Table 2 - Causes indicated as most important for the respondents in 2013 and 2014

\begin{tabular}{c|c|c}
\hline Most Important Causes & $\mathbf{2 0 1 3}$ & $\mathbf{2 0 1 4}$ \\
\hline Public Transportation & $44,2 \%$ & $26,9 \%$ \\
\hline Criticism towards Government & $34,6 \%$ & $19,2 \%$ \\
\hline Corruption & $32,7 \%$ & $38,5 \%$ \\
\hline Lack of public education service & $28,8 \%$ & $55,8 \%$ \\
\hline Lack of public Health service & $19,2 \%$ & $34,6 \%$ \\
\hline Criticism towards Mass Media & $17,3 \%$ & $23,1 \%$ \\
\hline PEC 37 & $13,5 \%$ & $0,0 \%$ \\
\hline FIFA Pattern for public services & $11,5 \%$ & $9,6 \%$ \\
\hline Gay cause & $1,9 \%$ & $13,5 \%$ \\
\hline
\end{tabular}

Source: Author's data, social media mapping on-line.

- Is political engagement the main core of action?

The initial objective of this study was to identify the connection between political activism and social media. It sought to determine the relationship between online visibility/popularity and political engagement. The findings point out that a key factor of success in the communication for social change is the individual's wish to be part of a globally visible event, which will be attended by most of the people in their social network.

Using the digital research tool Google Trends, Moraes e Santos (2013) tested the frequency of certain terms related to the protests, and discovered that during the June 2013 uprisings in Brazil the frequency was greater for the keyword "protests" than other terms connected to the causes. Crossing Moraes e Santos' proposal with the semantic areas that have most emerged in the data provided by Interagentes agency, we have confirmed that "protests" was by far the keyword that was mostly searched on Google in that period.

This demonstrates that what attracted the masses was also the "event of a protest", besides its political roots or its consequences. Werneck (2015) calls this phenomenon "manifestism", stressing how fashionable the protests became in that moment, as an event that could not be missed. In his study on protestors' posters, the author analyzes a category of messages that refer to the protest itself, to the uncountable reasons that brought people to the streets, and their right to protest. Some examples are: "The people united is this huge amount of us", "It's too many reasons, they don't fit in a poster", "I want a bag of Louis Vitton" or "Only Goku 
will save us". At this respect, Castells (2012) points out that rather than requiring organisational control or a unified "we", these networks are based on a personal interpretation of the topics, and comprise of all the different individual views under the same claim. This model of action mirrors the need of the protesters to find a community beyond their differences, a space of flows and conviviality.

- Is social media perceived as a space for political action?

The results indicate that digital networks are considered a space of communication and a very powerful mean to call people to join an event, but they are not themselves a political space for debate.

In the Brazilian uprisings of June 2013, social media had the crucial role of giving visibility to the events on the streets. For the first time, mobile phones were massively used as a tool for information, this way also becoming a self-defense weapon. In the words of one interviewed activist:

When one of the guys of Mídia Ninja (alternative media source active during protests, editor's note) was taken by the police, I saw many people taking out their phones and starting to record and taking pictures, lots of people. And I suddenly realised there was something new happening at that moment. People wanted to be poles of information. And it's this way that it started. Many collectives were born with the idea of making independent information through the social media. In those days, big actions on the streets were tagged as "events" on Facebook, and this way it was easy to know how many said they'll participate. But other events were organised through chats online also. Social media have a great potential to mobilise people, for sure, but they're much more than that. During the events, people would have their cell phone in the hand, and they'd tell post online where the protest was moving, where the police was, what was happening in real time. So, not only people were moving thanks to social networks, but even political acts were moving constantly.

The awareness of participating in a global event was clear also in the intention of gaining visibility on digital networks: many banners were written in English, while the most popular Twitter hashtag \#VemPraRua (come to the street) echoed the one that was created by the Spanish Indignados movement in 2011, \#TomaLaCalle (take the street). And provocatively enough, it turned into a viral video clip borrowing the 
music from a TV commercial for the World Cup. Furthermore, the personalization of a message or the simple action of sharing it on a personal page/account would help the movement to constantly grow stronger. Institutional events would lose importance, while informal events would take priority in people's agendas. When the (online) network of friends would be involved, the individual did not want to feel excluded and would participate. As an event that could not be missed.

However, no evidence of an increase in political engagement was detected among the participants of the most active pages/account during protests. When asked about reasons for massive participation, all of them mentioned - among other reasons - the wish to party and celebrate the event itself. The comment below illustrates the disappointment that this caused in some of the activists who strongly believed in the uprisings as a chance for political change:

The majority of people were there for a party. Some of them even participated to the local meetings of the neighborhood, I saw them several time. They had lots of energy to fight against the system, but after a while they wouldn't come anymore. They wouldn't even answer to a message on Facebook. [...] It's a pity; it could have been a real opportunity for a change.

- What is left of the protests in present days?

Seen sometimes with nostalgia, sometimes as a necessary step towards the unknown, the protests of June 2013 are surely remembered as a historical event by the Brazilian youth. As one interviewee affirms:

June 2013 was a very interesting moment. One million people protesting on the streets. But it was also kind of "pyrotechnics" [...]. Some people say they miss that and they try to repeat it. I don't think that's this way. History does not have to repeat itself, now we've got to build something else, different springs and new 'Junes', movements that will use different "weapons" than the ones the police is using: not violence, but art, performance, playfulness, communication channels. Sometimes, a performance can be a space for greater peoples' identification and recruitment rather than a Molotov. I think we should look now for cleaver and powerful actions, and not just reproduce what happened in 2013. 
Activists mentioned some interesting actions and happenings that took place in Rio de Janeiro after the first protests, and which could enter in the category of art and playfulness: a black gay man dressed as Spiderman dancing in front of the Riot Police, the Poor Batman character who was acting in defense of the homeless with many performances during the protests, and a whole movement named "Carnavandalirization", which was created by a group of artists in July 2013 and aimed at answering violence with glitter and original Carnival costumes. One informant reported:

When we started to prepare for the World Cup, we had the idea to oppose to the image of violence in protests that was built by the media... Police on one side and black block on the other. We used language, choreography and aesthetics typical of Carnival as a form to protest and manifest. We didn't want to have an aggressive attitude towards football, giving the fact that Brazilians love it so much. We wouldn't have conquered anybody. Besides, people were scared about protesting. So, our purpose was to soften violence itself, and minimise the critiques of who was judging us because we were manifesting our ideas. When you bring creativity and the effort to prepare all the costumes and the parade - we did it as if it was really Carnival! In front there were the pink block and every sector had its own specific topic - well, this way it's easier to conquer people.

Gutierrez (2013) argues that global protests have had no aim at destroying the power structure. Rather, they used tactics that were meant to provoke, like throwing glitter at the police or hula hooping in front of the Town Hall, as happened during protests in Rio de Janeiro. These actions might be subversive and effective enough to challenge the institutional authorities, without constituting real danger.

Interestingly enough, even though they recognise the importance of the uprisings of June 2013, all the activists interviewed for this research did not find that the energy collected and expressed by people at that time was dispersed when the wave of protests ended. On the contrary, they saw in that specific event the chance to meet people who felt the same way towards the crises of political representativeness, and new forms of action were forged at that moment, which most of them called "resistance". This view was echoed by several informants, as these comments illustrate: 
The street was a stage of class mixture, ideologies and strategies. The centre of the city met the suburbs, and people who would have never had the chance to meet, are interacting for the first time. [...] Collectives were born in these meetings, and they started to produce information during the protests already, with the goal of documenting in real time what was happening on the street.

There were very few people from the favelas, I know because I live in a favela myself and I can recognise them, especially by their way of talking. I went to the streets by myself, and there I met 5 or 6 guys from other favelas. None of them was militant before, but they all got involved in some political action after the protests, including myself. [...] That was a very special moment, I didn't know anybody from middle class who'd be interested in doing something together, now I know lots of people and we're always organizing meetings, speeches, every time somewhere else. The purpose is to awake the people who live in the favelas, shake them from the alienation. Make them conscious about political problems, things they can have a word about.

Many things are already happening in the favelas, there's a new movement, a new interest in independent information and activism. Pedagogical work has started in 2013. It's just small seeds, but they can bring about some more solid change in the future.

Surprisingly, political engagement was found to increase in smaller circles, among groups of youth who got involved during the uprisings, and continue to be motivated by the idea of a political change up to present days. This unexpected finding suggests that massive movements are not as important as local and more continuous actions. In fact, since June 2013, digital networks have turned into concrete social networks, which have increased the opportunities of political resistance for the Brazilian civil society.

\section{Conclusions}

In conclusion, two key factors of success in the communication dynamics appeared crucial in the presented case study: (1) The presence of influential authorities or choreographers (GERBAUDO, 2012) involved in logistics and 
organisation; and (2) The wish of the youth to be part of a globally visible event, which will be attended by most of the people in their social network.

The unexpected finding is that political actions have continued at a local level after 2013 protests. The uprisings might not repeat, or at least not with the same format and/or amount of participants. Nevertheless, they represented a historical event because they gathered not only a massive amount of people, but also people who were united in their difference. Small but continuous work of resistance has been done through these networks, groups, and collectives since then. Thanks to that special event: they were able to build relationships which overcome social distance and inequalities, create new spaces for creativity every day, empower the powerless and give them hope for the future.

Magda Pischetola é Doutora em Educação. Professora Assistente da Pontificia Universidade Católica do Rio de Janeiro, no Departamento de Educação. E-mail: magda@puc-rio.br.

\section{Referências}

BENNETT, Lance; SEGERBERG, Alexandra. The Logic of Connective Action: Digital media and the Personalization of Contentious Politics. New York: Cambridge University Press, 2013.

BENNETT, Lance; SEGERBERG, Alexandra; WALKER, Shawn. Organization in the crowd: peer production in large-scale networked protests. Information, Communication and Society, v. 17, Issue 12, 2014.

CASTELLS, Manuel. Networks of Outrage and Hope: Social Movements in the Internet Age. Cambridge, UK: Polity Press, 2012.

CHADWICK, Andrew. Politics and Communications in the Hybrid Media System. Hanover Communications Blog, October 7, 2013.

GERBAUDO, Paolo. Tweets and the Streets. Social Media and Contemporary Activism.London: Pluto Press, 2012.

GUTIERREZ, Bernardo. As revoltas em rede como uma nova arquitetura do protesto. Revista Alegrar, n. $12,2013$. 
46 | Magda Pischetola

INTERAGENTES. Cartografia de espaços híbridos: as manifestaçóes de junho de 2013. Available at http://portal.interagentes.cc/?p=62. Last Access: July $18^{\text {th }} 2014$.

KLEINBERG, Jon Michael. Authoritative Sources in a Hyperlinked Environment. Journal of the $A C M$, v. 46, n. 5, p. 604-632, 1999.

MORAES, Thiago Perez Bernardes; SANTOS, Romer Mottinha. Os protestos no Brasil. Um estudo sobre as pesquisas na web, e o Caso da Primavera Brasileira. Rev. Int. Inv. Cienc. Soc., v. 9, n. 2, diciembre 2013, p. 193-206, 2013.

PISCHETOLA, Magda. Protests in Brazil: the Role of Social Media in Political Action. Social Media and the Transformation of Public Space Congress. University of Amsterdam, The Netherlands, June 18-20, 2014.

REEDY, Justin; WELLS, Chris. Information, the Internet and Direct Democracy. In: CHADWICK, Andrew; Howard, Philip Howard (eds.). Routledge Handbook of Internet Politics. p. 157-172. London and New York: Routledge, 2009.

SANTOS, Reinaldo dos. Mídia, democracia e participação efetiva: liberdade, igualdade e participação política. Word presented in XXXII Congresso Brasileiro de Ciências da Comunicação, Curitiba/PR, 2009.

DIJK, Jan A.G.M. Digital Democracy: Vision and Reality. In: SNELLEN, Ignace; VAN DE DONK, Wim (orgs.). Public Administration in the Information Age: Revisited. Amsterdam: IOS Press, 2012.

WERNECK, Alexandre (org.). Violências moduladas: gramáticas e dispositivos da crítica e da negociação na conflitualidade urbana no Rio de Janeiro. Relatório de pesquisa. Rio de Janeiro, Fundação Carlos Chagas Filho de Amparo à Pesquisa do Estado do Rio de Janeiro (Faperj). Unpublished research report, Universidade Federal do Rio de Janeiro, 2015.

Texto recebido em 05 de maio de 2016. Aprovado em 18 de julho de 2016. 